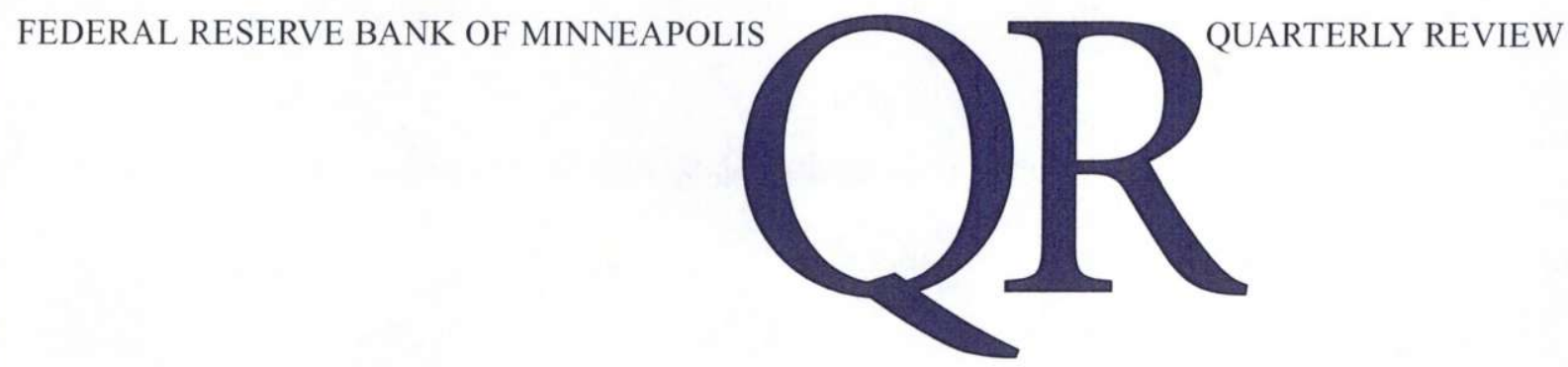

September 2006

Latin America

in the Rearview Mirror

Harold L. Cole

Lee E. Ohanian

Alvaro Riascos

James A. Schmitz Jr.

Early State Banks in the United States: How Many Were There and When Did They Exist?

Warren E. Weber 


\section{FEDERAL RESERVE BANK OF MINNEAPOLIS}

\section{Quarterly Review vol. 30, No.1}

\section{ISSN 0271-5287}

This publication primarily presents economic research aimed at improving policymaking by the Federal Reserve System and other governmental authorities.

Any views expressed herein are those of the authors and not necessarily those of the Federal Reserve Bank of Minneapolis or the Federal Reserve System.

EDITOR: Arthur J. Rolnick

ASSOCIATE EDITORS: Patrick J. Kehoe, Warren E. Weber

ARTICLE EDITOR: Joan M. Gieseke

PRODUCTION EDITOR: Joan M. Gieseke

DESIGNER: Phil Swenson

TYPESETTING: Mary E. Anomalay

CIRCULATION ASSISTANT: Mary E. Anomalay
The Quarterly Review is published by the Research Department of the Federal Reserve Bank of Minneapolis. Subscriptions are available free of charge. This has become an occasional publication, which is published once or twice a year. The publication, however, continues to be known as the Quarterly Review for citation purposes.

Quarterly Review articles that are reprints or revisions of papers published elsewhere may not be reprinted without the written permission of the original publisher. All other Quarterly Review articles may be reprinted without charge. If you reprint an article, please fully credit the source-the Minneapolis Federal Reserve Bank as well as the Quarterly Review-and include with the reprint a version of the standard Federal Reserve disclaimer (italicized left). Also, please send one copy of any publication that includes a reprint to the Minneapolis Fed Research Department.

Electronic files of Quarterly Review articles are available through the Minneapolis Fed's home page on the World Wide Web:

http://www.minneapolisfed.org.

Comments and questions about the Quarterly Review may be sent to:

Quarterly Review

Research Department

Federal Reserve Bank of Minneapolis

P. O. Box 291

Minneapolis, MN 55480-0291

(Phone 612-204-6455/Fax 612-204-5515)

Subscription requests may be sent to the circulation assistant at mea@res.mpls.frb.fed.us. 


\title{
Early State Banks in the United States: How Many Were There and When Did They Exist?*
}

\author{
Warren E. Weber \\ Senior Research Officer \\ Research Department \\ Federal Reserve Bank of Minneapolis
}

In this article I describe a newly constructed census of the state banks that existed in the United States prior to the Civil War. Specifically, this data set is a compilation of the names and locations of all banks that existed between 1782 and 1861, an estimate of the date at which each began business, and an estimate of the date at which a bank went out of business if it was not in business on December 31, 1860. The study ends with this date because the Civil War began shortly thereafter.

The identification of banks and the estimates of their period of operation are based primarily on when they were listed in published bank balance sheets or in banknote reporters. Beginning and ending dates from secondary sources are also used in some cases. The dates banks were in existence are used to construct time series of the number of banks in existence by state and in the aggregate. I use these series to establish some facts about the magnitude and timing of changes in the number of banks and how these changes differed by state.

Two previously published time series have provided data on the number of banks that existed in the country during this period. Fenstermaker's series is based on his compilation of the dates when banks were chartered. ${ }^{1}$ It is annual for the period 1782-1838. The second is compiled from various U.S. House and Senate Executive Documents. It covers selected years before 1834 and is annual after that, with the exception of $1852 .{ }^{2}$ This series is sometimes based on the number of bank charters in existence on a given date and sometimes based on the number of banks reporting their condition around a given date.

There are consistency, accuracy, and timing problems with one or both of these series. The congressional documents series is inconsistent in how it treats savings institutions and bank branches over time. Also, for some years not all states are included. Fenstermaker's series is consistent. He counts only chartered banks and covers all states.

With regard to accuracy, counting the number of banks by the number of charters may lead to overstating the number of banks in operation at a point in time for two reasons. First, banks that were granted charters but failed to open could be included. Second, and more importantly, typically there was a lag between when a bank was granted a charter and when it opened its doors for

*Copyright 2006, Economic History Association; reproduced with permission of the Economic History Association.

The author thanks two referees for useful comments and suggestions.

${ }^{1}$ Fenstermaker, Development.

${ }^{2}$ I have relied on the original Executive Documents rather than the series published in the 1876 Report of the Comptroller of the Currency. In this way, I have been able to determine the number of banks by state. 
business. Thus, using initial chartering dates may count some banks as being in operation before they actually were. My approach does not suffer from this problem. For most banks I do not use charter dates to determine when they began business. Further, in those cases when I do use charter dates as the basis of this determination, I make an adjustment for the lag between receipt of a charter and the beginning of operations.

The procedure of counting the number of banks in existence at a point in time based on the number reporting their condition around that time may also lead to miscounting the number of banks in operation. Relying strictly on banks' report of condition can lead to an undercounting of the number of banks in operation because there were times when not all banks reported their condition when required. Combining information from condition reports from states taken at different times may lead to either an under- or overcounting of the number of banks in operation. For example, suppose the condition report for banks in state A was for August 31 of a certain year, for banks in state B it was for December 31 of that year, and the series date is given as December 31 . There is no guarantee that the number of banks in state A remained unchanged between August 31 and December 31. The number could have increased or decreased. My method does not have this problem because I count the number of banks in operation for a given day based on my estimates of the dates they were open for business.

With regard to timing, the previously published series are at annual intervals. As a result, they cannot identify within-year fluctuations in the number of banks, such as was the case during the Panic of 1857 . I can identify within-year fluctuations because my method for counting banks yields a daily series.

My by-state and aggregate series agree with these previously published series in broad outlines. However, for the majority of dates for which there are Fenstermaker or congressional documents series, my count of the number of banks and branches does not agree with either. Of course, my procedure is also not completely accurate. In particular, my bank starting dates are biased toward being too late. Banks were only required to report their condition periodically. The banknote reporters I relied on were only published monthly, and banks may have appeared in them with a lag. Nonetheless, I argue below that my series are superior to the previously published ones.

\section{Methodology}

\section{Definition of a Bank}

Before the number of banks that existed during this period can be determined, three issues must be resolved. The first is which financial institutions should be classified as banks. I count as a bank a financial institution that was chartered by a state or was established under a "free banking" law and was legally permitted to issue notes-bearer instruments (pieces of paper) that were liabilities of the issuer and redeemable in specie on demand. The "savings institutions" that existed in Kentucky, Maryland, and Pennsylvania are not banks under this definition because they could not legally issue notes. The numerous "private banks" that existed during this period are also excluded because they were not chartered and could not legally issue notes. ${ }^{3}$ Also, I exclude the First and Second Banks of the United States because they were federally chartered. The continuation of the Second Bank of the United States after it lost its federal charter in 1836 is also not included, even though it technically was a Pennsylvania chartered bank at this time.

The second issue to resolve is whether a bank that ceased operations and then restarted sometime later should be counted as a single bank or as two banks. I have opted to count such occurrences as two separate banks. The same is true of banks in New Hampshire that lost their charters or had their charters expire and then resumed operations, essentially as new banks, shortly thereafter.

The third issue is whether to include bank "agencies" and "offices of discount and deposit" as branches. I have chosen to exclude them because they did not offer a full range of banking services; in particular, they did not issue notes. Including them would not greatly affect the branch counts as there were not many of them, except in Louisiana as discussed later.

\section{Determining the Number of Banks and Branches}

I use three sources to determine the names and locations of all state banks that existed during the period. The first is the reported balance sheets of state banks. I have collected a large number of balance sheets for banks that

\footnotetext{
${ }^{3}$ Some of these institutions were listed in some of the reported bank balance sheets for these states. Further, an examination of the detailed listings of due to other banks and due from other banks in the balance sheets of Pennsylvania banks in the 1850 s reveals that such institutions had financial relationships with banks (see Weber, "Interbank Payments"). Nonetheless, I have not included them because they did not fit my definition.
} 
existed during this period. ${ }^{4} \mathrm{~A}$ total of 2,089 banks appear in these balance sheets.

Not all banks that existed during this period are covered in the balance sheets, however. Some banks did not have to report to state authorities. Others did not last for long and had disappeared by the time they had to report to state authorities. Thus, I use banknote reporters from the period as a second source for names and locations of banks. These banknote reporters listed virtually all banks in the country as part of their presentation of discounts on banknotes and known counterfeits. I have found banknote reporters published in New York beginning in 1817 and published in Philadelphia beginning in 1830. For several years, especially early on, the New York listings were only for all banks in a particular state or a particular city. However, later issues listed banks individually. The Philadelphia issues always listed banks individually. Financial institutions that were listed in these publications but for which I have not found balance sheets are counted as banks, subject to one qualification. Fraudulent or questionable institutions posing as banks and issuing notes also sometimes appeared in these publications. Thus, I include institutions listed in banknote reporters only if they are also listed by James Haxby, Fenstermaker, or William Dillistin. ${ }^{5}$ Another 136 banks are added in this way.

The written reports of state banking authorities are a third source of information on banks. In several of these reports I found listings of the rates at which the state banking authorities were redeeming the notes of banks that had gone out of business. In these listings were three banks that existed late in the period but which did not appear in any balance sheet or banknote reporter. These were the Boone County Bank in Indiana, the Bank of Rochester in Minnesota, and the Farmers and Mechanics Bank of Onondaga in New York. I added these to the total.

Further, some banks were only in existence early in the period, either before the time I was able to obtain balance sheets or during periods when the New York banknote reporters did not list individual banks. To account for these banks, I use Haxby, Fenstermaker, or Dillistin as a third source. If an early financial institution was listed in two of these sources, I include it as a bank. Another 63 banks are added this way.

Thus, counting all banks I find a total of 2,291 banks that had been in business at some time between March 24, 1782 - the date at which the first bank in the country, the Bank of North America in Philadelphia, began - and December 31, 1860.
I use the same basic procedure to determine the number of bank branches that had been in business during this period. I find that a total of 386 branches had been in existence at some time during this period.

\section{Determining the Period of Operation}

To determine when each of these banks was open for business, I date a bank's beginning as the earliest date at which it appeared either in a report to a state banking authority or in a banknote reporter. The beginning dates for 1,868 banks are determined this way. Beginning dates for many of the remaining banks come from secondary sources. ${ }^{6}$ Regarding ending dates, 1,371 banks were in existence on December 31, 1860, so it is not necessary to determine ending dates for them. For the remaining banks, in most cases I consider the date at which they went out of existence to be the last date they appeared either in a report to a state banking authority or in a banknote reporter.

However, there are some exceptions. My detailed procedure for determining beginning and ending dates is described in an appendix to this article available on my Web site. I use the same method to determine that period of operation for bank branches. My compilation of the number of banks and branches, their locations, and the period in which I estimate they were in existence also can be found on my Web site.

\section{Total Number of Banks and Branches over Time}

Using my definition of a bank and my method for determining beginning and ending dates, I estimate the number of banks in operation in the United States for the period $1782-1861$. Because the dates of reported balance sheets and banknote reporters were not always the first or last day of a month, my count of banks is daily. Beginning-of-year estimates of the number of banks and branches by state are given in Table 1 . The daily series are available on my Web site. I now discuss some of the facts about the number of banks and branches shown by my series.

\footnotetext{
${ }^{4}$ This collection of balance sheets, which contains the vast majority of those extant, are available on my Web site: http://www.minneapolisfed.org/research/ economists/wweber. html.

${ }^{5}$ Haxby, Standard Catalog; Fenstermaker, Development; and Dillistin, Directory and Historical Directory.

${ }^{6}$ The secondary sources I used are Bentley, "Financial Institutions"; Bryan, History; Cable, Bank; Cole, Development; Dillistin, Directory and Historical Directory; Dowrie, Development; Fenstermaker, Development; French, Banking; Hasse, History; Haxby, Standard Catalog; Holdsworth, Financing an Empire; Huntington, "History"; Kelly, Shank, and Gordon, Catalogue; Krause, Wisconsin Obsolete Bank Notes; Lesesne, Bank; Neale, "History"; Root, "Twenty Years"; Walsh, Early Banks; and Weems, "Bank."
} 


\section{2-1820}

The period 1782-1820 was one of rapid growth in the number of banks in the country. There was only a single bank in the country from March 1782 to March 1784, when a second bank was chartered. After that, the number of banks grew almost continuously until early November 1820, when there were 266 banks and 66 branches in existence, according to my estimates. At the end of 1820, banks existed in 23 states, the District of Columbia, and what were to become the states of Michigan and Missouri. In general, the number of banks established in New England and the Middle Atlantic states was larger than in the South and West. One exception was Ohio, which had 21 banks in November 1820. Also, even though North Carolina and Virginia had only three and four banks, respectively, banks in their states were permitted to establish branches, which they did.

A large number of bank closings and failures occurred during this period. Most states experienced at least one bank closing or failure. The first bank to go out of business was the Merrimack Bank in Newburyport, Massachusetts, which closed in June 1805. Between that date and the end of 1820, 51 banks went out of business in 13 states and in the territories of Michigan and Missouri. The largest number of closings and failures occurred in Kentucky (15). Massachusetts and Pennsylvania had seven failures each.

\section{0-1822}

The country's first substantial and extended decline in the number of banks occurred during this period. The decline began in November 1820 and continued until the beginning of January 1822. Over this 14-month period, the number of banks in existence fell by almost one-tenth, from 266 to 242 . This decline was associated with the Panic of 1819 and the subsequent recession. The bank closings during this period of declines were primarily in Ohio (8), Pennsylvania (7), and Maryland (5), although Delaware, Illinois, Indiana, Missouri, and the District of Columbia each experienced one or two bank closings. The closing of its two banks left Missouri without any banks. It did not have one again until May 1837.

\section{2-1840}

Another period of rapid growth in the number of state banks started at the beginning of June 1822 and lasted until late November 1840 when 702 banks were doing business. Although the growth in the number of banks was fairly steady over this period, the number of banks increased markedly around two separate time periods. The first was around August 1832. According to my series, 387 banks were in operation at the end of July 1832; a month later, at the beginning of September, that number had increased to 426 banks. The majority of these new banks were located in Massachusetts (22). No other state added more than five new banks. I do not know the reason for the large increase in Massachusetts banks at this time.

The second rapid increase in the number of banks was around August 1836. According to my series, 578 banks were in operation at the end of July 1836; a month later, at the beginning of September, that number had increased to 624 banks. Virtually all of these new banks were established in Massachusetts (26) and Maine (18). Once again, I do not know a reason for the large increases in the number of banks in these states.

This period contains the Panic of 1837, which occurred in May of that year. A nationwide bank suspension of specie payments lasted from May 10, when the banks in New York suspended, until May 1838 when banks in New York and New England resumed payments, although banks in the rest of the country did not resume until later in that year. ${ }^{7}$ It might be expected that the number of banks in the country would decline at such a time. Instead, the number of banks actually increased. By my estimate, 666 banks were in business on May 10, 1837; 674 were in business at the end of May one year later.

To be sure, bank closings and failures occurred over this period. I estimate that 35 banks went out of business in six states from the beginning of the panic until the end of April 1838. However, 20 of these closings and failures were of the 39 new banks established in Michigan subsequent to that state's passage of the first "free banking" legislation in March 1837. These banks only show up in the daily series because most of them started business around February 1838 and closed within two months. Given that these banks were established during a time when banks throughout the country had suspended spe-

\footnotetext{
${ }^{7}$ The first suspensions occurred in Natchez, Mississippi, on May 4, 1837. On May 10 the banks in New York suspended. The next day, the banks in Albany, Philadelphia, Baltimore, Hartford, and New Haven suspended. Banks in Boston and Mobile suspended the day after that, and banks in New Orleans suspended on May 13 Banks in Charleston and Cincinnati suspended on May 17; those in Kentucky and North Carolina on May 19. By the end of May, virtually all banks in the country had suspended specie payments.
} 
Table 1 U.S. Banks and Branches (Italics) by State, 1783-1861

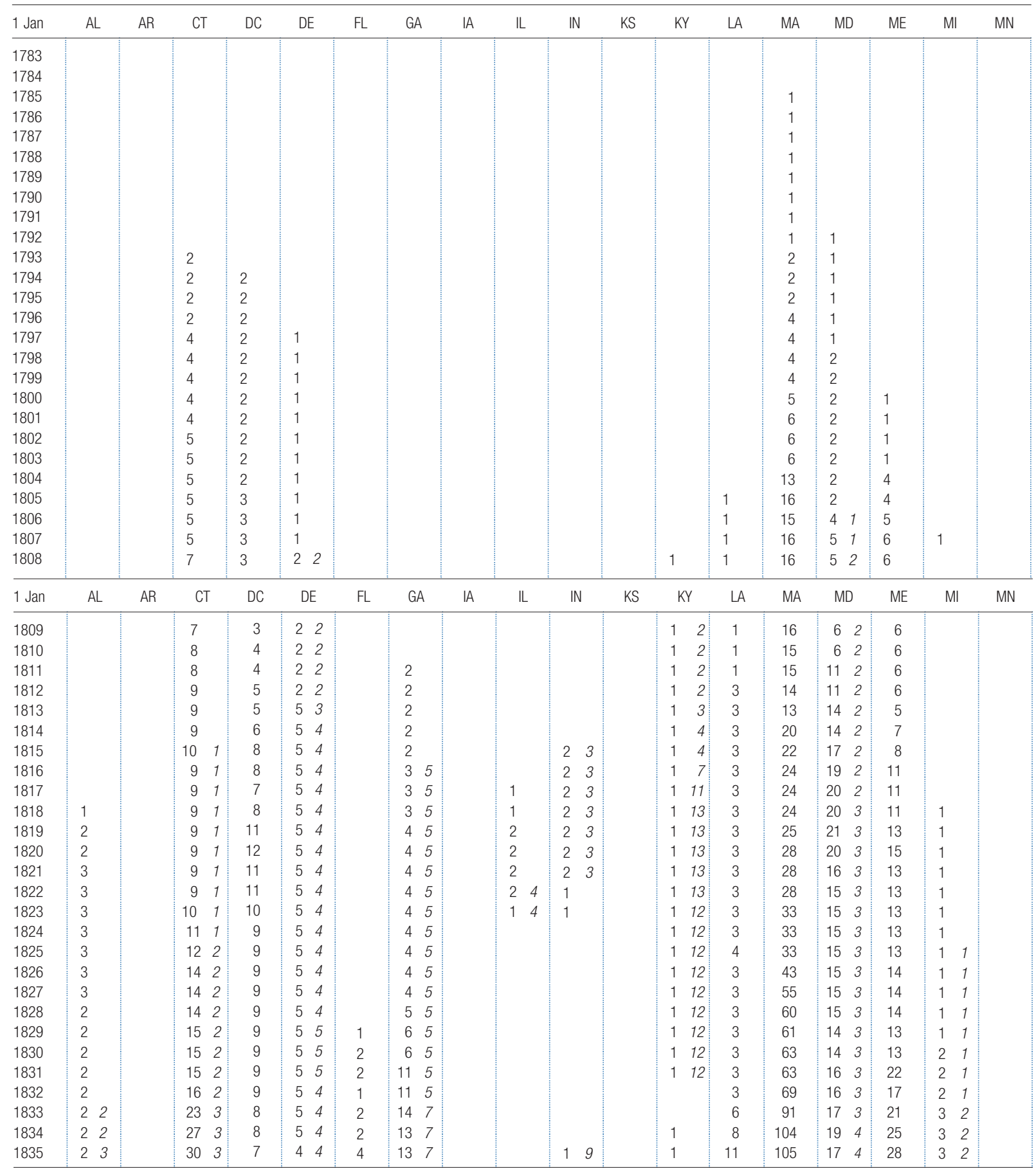


Table 1-continued (AL-MN)

\begin{tabular}{|c|c|c|c|c|c|c|c|c|c|c|c|c|c|c|c|c|c|c|c|c|c|c|c|c|c|c|}
\hline 1 Jan & $\mathrm{AL}$ & AR & CT & T & $D C$ & $\mathrm{DE}$ & & $F L$ & & $\mathrm{GA}$ & $\mathrm{IA}$ & IL & - & IN & & KS & & YY & LA & MA & $\mathrm{ML}$ & & ME & MI & & $\mathrm{MN}$ \\
\hline 1836 & 24 & & 31 & & 7 & 4 & & 2 & 13 & 9 & & 2 & 4 & 11 & & & 3 & & 12 & 105 & 19 & & 36 & & & \\
\hline 1837 & 34 & & 31 & & 7 & 4 & & 4 & 15 & 9 & & 2 & 5 & 11 & & & 3 & & 16 & 132 & 24 & & 55 & 9 & & \\
\hline 1838 & 34 & 12 & 31 & & 7 & 4 & & 4 & 18 & 17 & & 2 & 6 & 11 & & & 3 & 10 & 16 & 127 & 25 & & 55 & 34 & & \\
\hline 1839 & 34 & 12 & 31 & 3 & 7 & 4 & & 4 & 22 & 17 & 1 & 2 & 9 & 11 & & & 3 & 10 & 16 & 118 & 25 & & 52 & 17 & & \\
\hline 1840 & 34 & 16 & 31 & 3 & 6 & 53 & & 4 & 23 & 17 & 1 & 3 & 11 & 11 & & & 3 & 10 & 16 & 116 & 23 & & 51 & 4 & 2 & \\
\hline 1841 & 34 & 27 & 31 & 3 & 6 & 53 & & 5 & 22 & 15 & 1 & 3 & 13 & 11 & & & 3 & 10 & 16 & 116 & 23 & & 47 & 5 & 3 & \\
\hline 1842 & 34 & 27 & 31 & 3 & 6 & 53 & & 3 & 16 & 12 & 1 & 3 & 13 & 11 & & & 3 & 11 & 6 & 114 & 22 & & 40 & 4 & 1 & \\
\hline 1843 & 24 & 27 & 31 & 3 & 6 & 53 & & 3 & 14 & 8 & 1 & 1 & & 11 & & & 3 & 11 & 6 & 110 & 23 & 3 & 39 & 5 & 1 & \\
\hline 1844 & 1 & 27 & 31 & & 6 & 53 & & 3 & 12 & 8 & 1 & & & 11 & & & 3 & 11 & 6 & 109 & 23 & & 35 & 6 & 1 & \\
\hline 1845 & 1 & & 32 & & 5 & 53 & & 3 & 12 & 8 & 1 & & & 11 & & & 3 & 11 & 6 & 109 & 22 & & 35 & 6 & 1 & \\
\hline 1846 & 1 & & 32 & 2 & 5 & 53 & & & 12 & 8 & 1 & & & 11 & & & 3 & 11 & 6 & 109 & 21 & & 35 & 6 & 1 & \\
\hline 1847 & 1 & & 32 & & 5 & 53 & & & 11 & 8 & 1 & & & 11 & & & 3 & 11 & 6 & 107 & 22 & & 35 & 3 & 1 & \\
\hline 1848 & 1 & & 33 & 2 & 4 & 53 & & & 11 & 7 & & & & 11 & & & 3 & 11 & 7 & 111 & 22 & & 30 & 3 & & \\
\hline 1849 & 1 & & 33 & 2 & 4 & 5 & & & 11 & 4 & & & & 11 & & & 3 & 11 & 7 & 114 & 23 & & 31 & 3 & & \\
\hline 1850 & 1 & & 41 & 2 & 5 & 6 & & & 11 & 4 & & & & 11 & & & 3 & 11 & 6 & 122 & 23 & 3 & 32 & 4 & & \\
\hline 1851 & 1 & & 42 & 2 & 5 & 6 & & & 10 & 4 & & & & 11 & & & 5 & 11 & 6 & 127 & 24 & 3 & 32 & 5 & & \\
\hline 1852 & 2 & & 51 & 1 & 6 & 6 & & & 11 & 4 & & & & 11 & & & 5 & 19 & 6 & 137 & 25 & & 39 & 6 & & \\
\hline 1853 & 3 & & 56 & 1 & 8 & & & & 10 & 4 & & 19 & & 121 & & & 7 & 19 & 5 & 136 & 24 & & 44 & 6 & 1 & \\
\hline 1854 & 4 & & 61 & 1 & 8 & 7 & & & 13 & 4 & & 31 & & 341 & & & 8 & 23 & 7 & 151 & 25 & 1 & 60 & 7 & 1 & \\
\hline 1855 & 4 & & 66 & 1 & 6 & 7 & & & 16 & 4 & & 28 & & $\begin{array}{ll}36 & 1\end{array}$ & & & 6 & 23 & 7 & 157 & 27 & 1 & 71 & 4 & 1 & \\
\hline 1856 & 5 & & 70 & 1 & 6 & 8 & & & 20 & 4 & & 35 & & 371 & & & 6 & 24 & 8 & 169 & 28 & 1 & 74 & 5 & 1 & \\
\hline 1857 & 5 & & 72 & 1 & 6 & 9 & & & 23 & 4 & & 47 & & 37 & & & 7 & 24 & 8 & 172 & 30 & 1 & 75 & 5 & & \\
\hline 1858 & 6 & & 75 & 1 & 6 & 9 & & & 29 & 4 & & 47 & & 241 & & & 8 & 24 & 11 & 173 & 29 & 1 & 72 & 5 & & \\
\hline 1859 & 6 & & 73 & 1 & 6 & & & & 26 & 4 & & 51 & & 221 & & & 8 & 25 & 11 & 174 & 29 & 1 & 70 & 4 & & 2 \\
\hline 1860 & 8 & & 73 & 1 & 6 & 9 & & & 25 & 4 & 111 & 76 & & 181 & & 1 & 9 & 30 & 11 & 176 & 29 & 1 & 69 & 4 & & 7 \\
\hline 1861 & 7 & & 74 & 1 & 6 & 9 & & & 25 & 4 & 111 & 101 & & 181 & & 1 & 9 & 30 & 11 & 178 & 28 & 1 & 69 & 4 & & 5 \\
\hline
\end{tabular}

cie payments and went out of business before most of the country's banks had resumed, their demise should probably be attributed to shoddy or fraudulent banking practices rather than to the suspension per se.

A second round of suspension of payments began in Philadelphia on October 9, 1839, and quickly spread to banks in the South and West. Although 11 banks in six states closed or failed between then and January 1, 1840, the number of banks actually increased over that time. The reason was the establishment of 17 free banks in New York at the beginning of 1840, so that I count 712 banks as doing business on this date.

\section{0-1845}

The longest sustained decline in the number of banks and branches in the United States prior to the Civil War occurred during this period. The decline started at the beginning of January 1840 and lasted until February 1844. Over that period, the number of banks declined from 712 to 584 . This decline in the number of banks was the largest over any period prior to the Civil War, although in percentage terms, the decline in 1821 was larger. If one includes branches, then the decline continued even longer - until May 1845 when the number of banks and branches had declined from 845 on January 1,1840 , to 694 .

The decline in the number of banks from the beginning of January 1840 to February 1844 did not affect all states equally. The largest number of bank closings and failures occurred in New York (49), Ohio (27), Maine (16), Georgia (14), and Louisiana (10). In total, banks went out of existence in 18 states. However, a few banks did start up during this period (49 banks in 19 states). Overall, out of the 30 states with banks on January 1, 1840,12 of them had no change in their number of banks and two had increased their number of banks by February 1, 1844.

\section{$1845-1860$}

Over the 16-year period 1845-1860, the number of banks in the country rose almost steadily. On January 1, 1861, the number of banks in the country stood at 1,371, more than double the number on January 1, 1845. Including branches, the counts are 1,571 and 709, respectively. 
Table 1-continued (MO-WI)

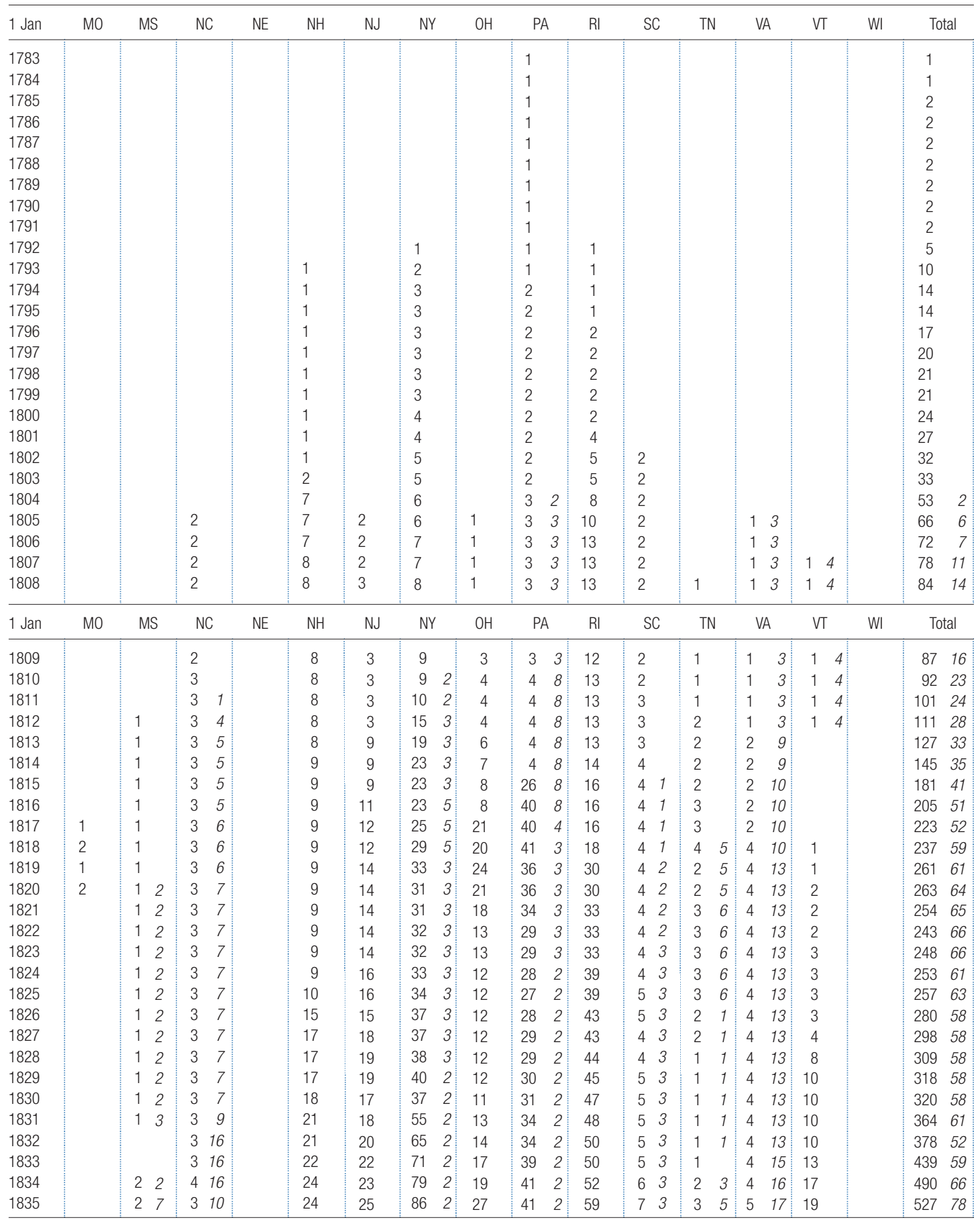


Table 1-continued (M0-WI)

\begin{tabular}{|c|c|c|c|c|c|c|c|c|c|c|c|c|c|c|c|c|c|c|c|c|c|c|c|c|}
\hline 1 Jan & & no & MS & $\mathrm{N}$ & C & NE & $\mathrm{NH}$ & $\mathrm{NJ}$ & NY & & $\mathrm{OH}$ & & PA & & $\mathrm{Rl}$ & SC & & TI & & VA & VT & WI & Tot & \\
\hline 1836 & & & 510 & & 13 & & 26 & 26 & 86 & & 30 & & 44 & & 61 & 8 & & 3 & 5 & $\begin{array}{ll}5 & 17\end{array}$ & 19 & 1 & 563 & 97 \\
\hline 1837 & & & 1116 & 3 & 15 & & 27 & 27 & 98 & & 32 & & 49 & 2 & 63 & 10 & 3 & 3 & 5 & $\begin{array}{ll}5 & 17\end{array}$ & 19 & 2 & 657 & 114 \\
\hline 1838 & 1 & 1 & 1416 & 3 & 12 & & 28 & 27 & 97 & & 33 & & 48 & 3 & 63 & 10 & 3 & 3 & 8 & $\begin{array}{ll}5 & 17\end{array}$ & 19 & 2 & 687 & 128 \\
\hline 1839 & 1 & 1 & 2116 & 3 & 12 & & 28 & 27 & 113 & 2 & 35 & & 48 & 3 & 63 & 11 & 3 & 4 & 15 & $\begin{array}{ll}6 & 17\end{array}$ & 19 & 2 & 688 & 138 \\
\hline 1840 & 1 & 2 & 95 & 3 & 13 & & 28 & 27 & 165 & 2 & 37 & & 49 & 3 & 63 & 12 & 3 & 4 & 15 & $\begin{array}{ll}6 & 17\end{array}$ & 17 & 1 & 712 & 133 \\
\hline 1841 & 1 & 2 & 2 & 3 & 13 & & 26 & 27 & 164 & 2 & 36 & & 49 & 3 & 63 & 12 & 3 & 4 & 15 & $\begin{array}{ll}6 & 17\end{array}$ & 17 & & 697 & 131 \\
\hline 1842 & 1 & 2 & 1 & 3 & 13 & & 23 & 25 & 145 & 2 & 35 & & 50 & 2 & 63 & 12 & 3 & 4 & 15 & 624 & 17 & & 644 & 133 \\
\hline 1843 & 1 & 2 & 1 & 3 & 13 & & 23 & 26 & 136 & 2 & 12 & & 47 & 2 & 63 & 12 & 3 & 4 & 15 & 624 & 17 & & 602 & 116 \\
\hline 1844 & 1 & 4 & 1 & 3 & 13 & & 20 & 26 & 134 & 2 & 10 & & 47 & 2 & 62 & 12 & 3 & 4 & 15 & 624 & 17 & & 584 & 114 \\
\hline 1845 & 1 & 4 & 1 & 3 & 14 & & 20 & 26 & 149 & 2 & 10 & & 47 & 1 & 62 & 12 & 3 & 4 & 15 & 624 & 17 & & 596 & 106 \\
\hline 1846 & 1 & 5 & 1 & 3 & 14 & & 18 & 26 & 149 & 2 & 10 & 15 & 47 & 1 & 62 & 12 & 3 & 4 & 16 & 624 & 17 & & 593 & 120 \\
\hline 1847 & 1 & 5 & 1 & 3 & 15 & & 17 & 26 & 151 & 2 & 19 & 17 & 47 & 1 & 62 & 12 & 3 & 4 & 16 & 624 & 17 & & 598 & 123 \\
\hline 1848 & 1 & 5 & 1 & 4 & 15 & & 20 & 24 & 171 & 2 & 20 & 29 & 47 & 1 & 63 & 12 & 3 & 3 & 15 & 627 & 18 & 1 & 622 & 135 \\
\hline 1849 & 1 & 5 & 1 & 4 & 15 & & 19 & 25 & 179 & 2 & 20 & 37 & 46 & 1 & 63 & 12 & 3 & 4 & 16 & 629 & 21 & 1 & 638 & 143 \\
\hline 1850 & 1 & 5 & 1 & 5 & 15 & & 22 & 25 & 184 & 1 & 18 & 40 & 47 & 1 & 62 & 12 & 3 & 4 & 17 & 630 & 23 & 1 & 666 & 147 \\
\hline 1851 & 1 & 5 & 1 & 5 & 15 & & 22 & 26 & 195 & 1 & 18 & 40 & 48 & 1 & 65 & 12 & 3 & 5 & 17 & 630 & 27 & 1 & 696 & 147 \\
\hline 1852 & 1 & 5 & 1 & 7 & 15 & & 27 & 40 & 224 & 1 & 29 & 40 & 49 & & 70 & 12 & 3 & 5 & 18 & 832 & 31 & 1 & 800 & 156 \\
\hline 1853 & 1 & 5 & 1 & 7 & 15 & & 31 & 44 & 242 & 1 & 28 & 40 & 49 & & 71 & 12 & 3 & 7 & 18 & 1033 & 33 & 1 & 873 & 158 \\
\hline 1854 & 1 & 5 & 1 & 10 & 16 & & 35 & 40 & 277 & & 27 & 40 & 50 & & 77 & 16 & 3 & 9 & 18 & 1537 & 33 & 11 & 1,018 & 166 \\
\hline 1855 & 1 & 5 & 1 & 10 & 16 & & 36 & 33 & 274 & & 243 & 38 & 51 & & 87 & 18 & 3 & 16 & 20 & 2038 & 39 & 26 & 1,071 & 167 \\
\hline 1856 & 1 & 5 & 1 & 12 & 16 & & 47 & 38 & 288 & & 243 & & 59 & & 92 & 18 & 3 & 27 & 19 & 2039 & 41 & 33 & 1,172 & 167 \\
\hline 1857 & 1 & & 1 & 12 & 16 & 3 & 49 & 46 & 307 & & 24 & & 57 & & 98 & 18 & 3 & 32 & 20 & 2241 & 41 & 49 & 1,256 & 156 \\
\hline 1858 & 6 & 4 & 2 & 12 & 16 & 6 & 52 & 48 & 298 & & 213 & & 76 & & 93 & 18 & 3 & 29 & 20 & $22 \quad 42$ & 40 & 74 & 1,291 & 176 \\
\hline 1859 & 7 & 14 & 2 & 12 & 16 & 1 & 52 & 49 & 299 & & 223 & & 79 & & 93 & 18 & 3 & 23 & 18 & $24 \quad 42$ & 41 & 104 & 1,317 & 184 \\
\hline 1860 & 9 & 29 & 2 & 13 & 16 & 1 & 51 & 49 & 299 & & 19 & & 80 & & 91 & 18 & 2 & 15 & 18 & $24 \quad 42$ & 41 & 109 & 1,345 & 214 \\
\hline 1861 & 9 & 33 & 2 & 13 & 16 & & 51 & 48 & 305 & & 193 & 37 & 80 & & 90 & 18 & 2 & 13 & 13 & $24 \quad 42$ & 40 & 111 & 1,371 & 213 \\
\hline
\end{tabular}

The two states with the largest banking systems posted two of the largest gains in the number of banks over this period-New York added 156 banks; Massachusetts, 69. Two other states that posted large gains - Wisconsin added 112 banks; Illinois, 101 — did not have any banks at the end of 1846 . Some other states with large increases in their numbers of banks were Connecticut (42), Maine (34), Missouri (8 banks, 29 branches), Ohio (9 banks, 37 branches), and Virginia (18 banks, 18 branches). By the end of 1860, 29 states, the District of Columbia, and the territory of Kansas had at least one bank. Without banks were the states of Arkansas, California, Oregon, and Texas and the territory of Nebraska.

An interesting feature of my aggregate bank series is that it indicates that the number of banks did not decline much during the Panic of 1857, which began during September of that year. My estimate is that 1,275 banks were in existence in the country on September 1, 1857. That number had fallen to only 1,266 banks toward the end of October, and the number of banks increased after that. An examination of the total bank starts and ends reveals that 26 banks went out of operation during this panic period, but this number was almost completely offset by 23 banks that began business.

\section{Comparison of My Series with Congressional Documents and Fenstermaker's Series}

In this section I compare my counts of the number of banks and branches in existence with the two previously published series - the one from congressional documents and the one from Fenstermaker. ${ }^{8}$ In the first subsection, I examine several cases in which my estimates are markedly different from these previously published ones and discuss how the differences arise. My purpose is to show that my series are more consistent and accurate than the previously published ones. In the second subsection, I discuss several episodes in which my daily series shows large, short-term changes in the number of banks that are not captured in the previously published series. The purpose here is to show that the daily timing of my series gives it another advantage over the previously published ones.

\footnotetext{
${ }^{8}$ Fenstermaker, Development.
} 


\section{Consistency and Accuracy}

Table 2 compares my series for the number of banks and branches in business on the first of the year for 17831861 with the series from congressional documents and Fenstermaker's series. Because the Fenstermaker series is essentially end-of-year, Table 2 lists his data as of the beginning of the subsequent year. The differences between my estimates and the congressional documents and between my estimates and Fenstermaker's count of charters are shown.

I begin by discussing large discrepancies between my series and the congressional series counts of banks. The first is in 1811, where I count 101 banks, but the congressional series says only 88 existed. Here the congressional series appears to be inaccurate because some states are omitted entirely and banks in some other states are undercounted. Specifically, Delaware seems to have been omitted from this count. It had two banks, chartered in 1796 and 1807, that were very likely doing business at the beginning of 1811. Also apparently omitted were three banks in Connecticut and two in New York that were likely doing business at the beginning of 1811 because they were chartered between 1806 and late March 1810. However, it also appears that I may have overstated the number of banks. Five banks were chartered in Maryland in December 1810. I count them as being in existence; the congressional series does not. Here the congressional series may be more accurate because the lag between obtaining a charter and beginning operations may have been longer than I assume in my procedure for determining when banks began operations. ${ }^{9}$

The next large discrepancies are for 1815,1816 , and 1820 . Here it appears that the congressional series overstates the number of banks in business. For 1815, the discrepancy is largely due to the count of the number of banks in business in Pennsylvania. The congressional series has 42; I count only 26. In March 1814 the Pennsylvania legislature granted 39 new bank charters. All of these are counted in the congressional documents series. However, John Holdsworth and Fenstermaker agree that three of these charters were never taken up. ${ }^{10}$ Further, based on Holdsworth and the fact that several of these newly chartered banks do not appear in the reported balance sheets of November 1814, I conclude that only 22 of these newly chartered banks opened by January 1,1815 . The other 13 opened later. In the case of 1816 , the problems occur in counting the banks in
Ohio and Virginia. The congressional series counts 13 Ohio banks as being in existence at the beginning of 1816 even though they were chartered later that year. It also counts all Virginia bank branches as banks in the 1816 count; they are not counted as separate banks in any other year.

For 1820 the discrepancy is due to a difference in counts of the number of banks in Kentucky. The congressional series counts 42 ; I count only one. I think the congressional series count is too high. According to Fenstermaker, 47 banks were chartered in Kentucky in January 1818. However, regarding 12 of them Haxby states, "It is unclear whether this bank opened." Further, another 20 of these banks do not appear in any of the balance sheets that cover the time before May 1, 1820, when these banks' charters were revoked. Thus, I assume these 20 banks also never opened and do not include them in my count. Of the remaining 15 , all but one only appear in a balance sheet dated either November 3,1819 , or November 8,1819 . According to my dating procedure, these 14 banks are estimated to have existed only on that date. Even if these banks were in business past the time of the balance sheet, it remains the case that the comptroller's count is too high.

Two more large discrepancies in the number of banks occur in 1841 and 1842. The discrepancy in 1841 is due almost entirely to the fact that the congressional series does not include the new banks in New York established under the free banking law. The discrepancy in 1842 is due to the fact that New York's free banks are still not included and that banks in Ohio are omitted from the count. New York's free banks did not start being included in the congressional series until 1844.

The large discrepancy in 1853 is largely due to the exclusion of many banks that were in business. Specifically, 49 banks that were in business in Pennsylvania and the 17 banks that were in business in Illinois on this date are not included. In addition, 15 banks that were in business in New Jersey according to Dillistin do not appear in the reported balance sheets for this date and therefore are not included in the congressional series. ${ }^{11}$

The final large discrepancies are those in 1855 and 1856 . Here the problem with the congressional

\footnotetext{
${ }^{9}$ I have been unable to determine from secondary sources when these banks actually went into operation. Bryan, History, discusses their being chartered but does not state when they went into operation.

${ }^{10}$ Holdsworth, Financing an Empire; and Fenstermaker, Development.

${ }^{11}$ Dillistin, Directory.
} 
Table 2 Comparison of Weber Series with Previous Series, 1783-1861

\begin{tabular}{|c|c|c|c|c|c|c|c|c|c|c|c|}
\hline \multirow[b]{2}{*}{ 1-Jan } & \multicolumn{3}{|c|}{ Weber Series } & \multicolumn{3}{|c|}{$\begin{array}{c}\text { Congressional } \\
\text { Documents }\end{array}$} & \multirow{2}{*}{$\begin{array}{c}\text { Fenster- } \\
\text { maker } \\
(3)\end{array}$} & \multicolumn{4}{|c|}{ Differences } \\
\hline & Total & $\begin{array}{l}\text { Banks } \\
\text { (1) }\end{array}$ & Branches & Total & $\begin{array}{c}\text { Banks } \\
(2)\end{array}$ & Branches & & Total & $\begin{array}{l}\text { Banks } \\
\text { (1)-(2) }\end{array}$ & Branches & $\begin{array}{l}\text { Banks } \\
(1)-(3)\end{array}$ \\
\hline 1783 & 1 & 1 & 0 & & & & 1 & & & & 0 \\
\hline 1784 & 1 & 1 & 0 & & & & 1 & & & & 0 \\
\hline 1785 & 2 & 2 & 0 & & & & 2 & & & & 0 \\
\hline 1786 & 2 & 2 & 0 & & & & 1 & & & & 1 \\
\hline 1787 & 2 & 2 & 0 & & & & 2 & & & & 0 \\
\hline 1788 & 2 & 2 & 0 & & & & 2 & & & & 0 \\
\hline 1789 & 2 & 2 & 0 & & & & 2 & & & & 0 \\
\hline 1790 & 2 & 2 & 0 & & & & 2 & & & & 0 \\
\hline 1791 & 2 & 2 & 0 & & & & 3 & & & & -1 \\
\hline 1792 & 5 & 5 & 0 & & & & 5 & & & & 0 \\
\hline 1793 & 10 & 10 & 0 & & 11 & & 12 & & -1 & & -2 \\
\hline 1794 & 14 & 14 & 0 & & & & 15 & & & & -1 \\
\hline 1795 & 14 & 14 & 0 & & & & 15 & & & & -1 \\
\hline 1796 & 17 & 17 & 0 & & & & 20 & & & & -3 \\
\hline 1797 & 20 & 20 & 0 & & & & 22 & & & & -2 \\
\hline 1798 & 21 & 21 & 0 & & & & 22 & & & & -1 \\
\hline 1799 & 21 & 21 & 0 & & & & 22 & & & & -1 \\
\hline 1800 & 24 & 24 & 0 & & & & 25 & & & & -1 \\
\hline 1801 & 27 & 27 & 0 & & & & 28 & & & & -1 \\
\hline 1802 & 32 & 32 & 0 & & 32 & & 32 & & 0 & & 0 \\
\hline 1803 & 33 & 33 & 0 & & & & 35 & & & & -2 \\
\hline 1804 & 55 & 53 & 2 & & & & 53 & & & & 0 \\
\hline 1805 & 72 & 66 & 6 & & & & 64 & & & & 2 \\
\hline 1806 & 79 & 72 & 7 & & 75 & & 71 & & -3 & & 1 \\
\hline 1807 & 89 & 78 & 11 & & & & 78 & & & & 0 \\
\hline 1808 & 98 & 84 & 14 & & & & 83 & & & & 1 \\
\hline 1809 & 103 & 87 & 16 & & & & 86 & & & & 1 \\
\hline 1810 & 115 & 92 & 23 & & & & 92 & & & & 0 \\
\hline 1811 & 125 & 101 & 24 & & 88 & & 102 & & 13 & & -1 \\
\hline 1812 & 139 & 111 & 28 & & & & 117 & & & & -6 \\
\hline 1813 & 160 & 127 & 33 & & & & 143 & & & & -16 \\
\hline 1814 & 180 & 145 & 35 & & & & 147 & & & & -2 \\
\hline 1815 & 222 & 181 & 41 & & 208 & & 202 & & -27 & & -21 \\
\hline 1816 & 256 & 205 & 51 & & 246 & & 212 & & -41 & & -7 \\
\hline 1817 & 275 & 223 & 52 & & & & 232 & & & & -9 \\
\hline 1818 & 296 & 237 & 59 & & & & 262 & & & & -25 \\
\hline 1819 & 322 & 261 & 61 & & & & 338 & & & & -77 \\
\hline 1820 & 327 & 263 & 64 & & 307 & & 341 & & -44 & & -78 \\
\hline 1821 & 319 & 254 & 65 & & & & 327 & & & & -73 \\
\hline 1822 & 309 & 243 & 66 & & & & 273 & & & & -30 \\
\hline
\end{tabular}

series is one of overcounting. Several inaccuracies in the congressional series occur in both years. For one, the number of New York banks that are actually in the balance sheet reports supposedly underlying the congressional series are 287 and 283, respectively, not 328 and 338 as reported. I cannot determine why there is this discrepancy. For another, savings institutions in Pennsylvania are counted as banks even though I do not think they should be classified as such. In 1855 there is another overcounting, in this case the number of banks in Massachusetts. The balance sheet reports on which the series is supposedly based has only 143 banks, but 157 are included in the congressional series. Again, I cannot determine why there is this discrepancy.

The congressional series also contains some inconsistencies. Each of the branches of the State Bank of 
QR

Table 2- continued

\begin{tabular}{|c|c|c|c|c|c|c|c|c|c|c|c|}
\hline \multirow[b]{2}{*}{ 1-Jan } & \multicolumn{3}{|c|}{ Weber Series } & \multicolumn{3}{|c|}{$\begin{array}{c}\text { Congressional } \\
\text { Documents }\end{array}$} & \multirow{2}{*}{$\begin{array}{c}\text { Fenster- } \\
\text { maker } \\
\text { (3) }\end{array}$} & \multicolumn{4}{|c|}{ Differences } \\
\hline & Total & $\begin{array}{c}\text { Banks } \\
(1)\end{array}$ & Branches & Total & $\begin{array}{c}\text { Banks } \\
(2)\end{array}$ & Branches & & Total & $\begin{array}{c}\text { Banks } \\
(1)-(2)\end{array}$ & Branches & $\begin{array}{c}\text { Banks } \\
(1)-(3)\end{array}$ \\
\hline 1823 & 314 & 248 & 66 & & & & 267 & & & & -19 \\
\hline 1824 & 314 & 253 & 61 & & & & 274 & & & & -21 \\
\hline 1825 & 320 & 257 & 63 & & & & 300 & & & & -43 \\
\hline 1826 & 338 & 280 & 58 & & & & 330 & & & & -50 \\
\hline 1827 & 356 & 298 & 58 & & & & 331 & & & & -33 \\
\hline 1828 & 367 & 309 & 58 & & & & 333 & & & & -24 \\
\hline 1829 & 376 & 318 & 58 & & & & 355 & & & & -37 \\
\hline 1830 & 378 & 320 & 58 & & 329 & & 369 & & -9 & & -49 \\
\hline 1831 & 425 & 364 & 61 & & & & 381 & & & & -17 \\
\hline 1832 & 430 & 378 & 52 & & & & 424 & & & & -46 \\
\hline 1833 & 498 & 439 & 59 & & & & 464 & & & & -25 \\
\hline 1834 & 556 & 490 & 66 & & 505 & & 517 & & -15 & & -27 \\
\hline 1835 & 605 & 527 & 78 & 678 & 557 & 121 & 558 & -73 & -30 & -43 & -31 \\
\hline 1836 & 660 & 563 & 97 & 689 & 566 & 123 & 584 & -29 & -3 & -26 & -21 \\
\hline 1837 & 771 & 657 & 114 & 787 & 633 & 154 & 703 & -16 & 24 & -40 & -46 \\
\hline 1838 & 815 & 687 & 128 & 829 & 663 & 166 & 729 & -14 & 24 & -38 & -42 \\
\hline 1839 & 826 & 688 & 138 & 840 & 662 & 178 & & -14 & 26 & -40 & \\
\hline 1840 & 845 & 712 & 133 & 892 & 722 & 170 & & -47 & -10 & -37 & \\
\hline 1841 & 828 & 697 & 131 & 780 & 619 & 161 & & 48 & 78 & -30 & \\
\hline 1842 & 777 & 644 & 133 & 711 & 563 & 148 & & 66 & 81 & -15 & \\
\hline 1843 & 718 & 602 & 116 & 716 & 581 & 135 & & 2 & 21 & -19 & \\
\hline 1844 & 698 & 584 & 114 & 696 & 578 & 118 & & 2 & 6 & -4 & \\
\hline 1845 & 702 & 596 & 106 & 707 & 580 & 127 & & -5 & 16 & -21 & \\
\hline 1846 & 713 & 593 & 120 & 707 & 587 & 120 & & 6 & 6 & 0 & \\
\hline 1847 & 721 & 598 & 123 & 715 & 591 & 124 & & 6 & 7 & -1 & \\
\hline 1848 & 757 & 622 & 135 & 751 & 622 & 129 & & 6 & 0 & 6 & \\
\hline 1849 & 781 & 638 & 143 & 782 & 654 & 128 & & -1 & -16 & 15 & \\
\hline 1850 & 813 & 666 & 147 & 824 & 685 & 139 & & -11 & -19 & 8 & \\
\hline 1851 & 843 & 696 & 147 & 859 & 731 & 128 & & -16 & -35 & 19 & \\
\hline 1852 & 956 & 800 & 156 & & & & & & & & \\
\hline 1853 & 1,031 & 873 & 158 & & 750 & & & & 123 & & \\
\hline 1854 & 1,184 & 1,018 & 166 & 1,208 & 1,059 & 149 & & -24 & -41 & 17 & \\
\hline 1855 & 1,238 & 1,071 & 167 & 1,307 & 1,163 & 144 & & -69 & -92 & 23 & \\
\hline 1856 & 1,339 & 1,172 & 167 & 1,398 & 1,255 & 143 & & -59 & -83 & 24 & \\
\hline 1857 & 1,412 & 1,256 & 156 & 1,416 & 1,283 & 133 & & -4 & -27 & 23 & \\
\hline 1858 & 1,467 & 1,291 & 176 & 1,422 & 1,284 & 138 & & 45 & 7 & 38 & \\
\hline 1859 & 1,501 & 1,317 & 184 & 1,476 & 1,329 & 147 & & 25 & -12 & 37 & \\
\hline 1860 & 1,559 & 1,345 & 214 & 1,562 & 1,392 & 170 & & -3 & -47 & 44 & \\
\hline 1861 & 1,584 & 1,371 & 213 & 1,569 & 1,396 & 173 & & 15 & -25 & 40 & \\
\hline
\end{tabular}

Sources: Congressional documents; and Fenstermaker, Development.

Ohio usually was counted as a bank. ${ }^{12}$ There are two inconsistencies here. The first is that this practice was not used for all Ohio observations. In 1853 the State Bank of Ohio, whose charter permitted branching, is counted as only a single bank. The more important inconsistency, however, is the treatment of the State Bank of Ohio relative to other state bank branching systems that had a similar structure. A case in point is the State Bank of Indiana. It was always counted as a single bank in the congressional series during its existence from 1834 to 1856 .

\footnotetext{
${ }^{12}$ The State Bank of Ohio originally consisted of 41 branches (no parent), but only 35 were still open after 1855 .
} 
Fenstermaker's series has the same number of banks or fewer banks than my series for most years. This discrepancy is to be expected because he does not take account of the possible delay between the granting of a bank's charter and when it actually came into existence. Also, he has devoted less attention to when banks went out of existence than I have. The exceptions to the general relationship between our two series are the years 1786 and $1806-1811$. The difference in 1786 is due to our differential treatment of the Bank of North America. Its charter was repealed by the state of Pennsylvania in September 1785 and then restored in March 1787. Because it technically was not a chartered bank during this time, Fenstermaker did not include it in his count. However, because the bank continued in business during this time, I count it as being in existence. For 1806-1810 the problem appears to be that Fenstermaker's reported totals do not agree with what I obtain from the by-state information that he also reports. When I recompute his totals based on his by-state information, the resulting totals agree with mine. The only year for which I cannot account for the differences between our series is 1811 . Based on all of this, my conclusion is that my series is more accurate than his for those years.

I now turn to discrepancies in the number of branches between the congressional series and mine. For 1835 through 1851, one reason for the difference is the treatment of the 22-31 offices of discount and deposit in New Orleans. The congressional series includes these as branches; I do not. This causes the congressional series number to exceed mine. Between 1840 and 1845 another reason for the difference between the series is that the congressional series omits the six branches of the Bank of the State of North Carolina and the seven branches of the Bank of the State of Arkansas that were in existence. From 1851 on, the discrepancy between the series can be accounted for almost exclusively by my treatment of the branches of the State Bank of Ohio mentioned previously. This causes my count of branches to exceed the congressional series. Finally, the 11 branches of the State Bank of Iowa in existence at the beginning of 1861 are omitted from the congressional series.

\section{Timing}

The second advantage of my series over the previously published ones is that my series capture data on a daily basis, while the previously published series include data from only once a year. This permits my series to capture several episodes in which large changes in the number of banks occurred within a period shorter than a year. Some of these episodes were already discussed. There are some others.

One is the large fluctuation in the number of branches between October and December 1822. The Bank of the Commonwealth of Kentucky opened 12 branches in October, and the Bank of Kentucky, Frankfort, closed its 13 branches in December.

Three more examples are short periods during which there were large declines in the number of banks during the 1850s. One was between the middle of August and the end of November 1854 when the number of banks in the country fell by 72 . In large part, this decline was due to events in Indiana. Indiana passed a free banking law on May 28, 1852. Subsequent to the passage of that legislation, the number of banks in that state went from eight banks at the end of 1852 , to 33 at the end of 1853 , to a high of 76 at the beginning of November 1854 . However, a majority of these banks were short-lived; 42 went out of existence during November 1854.

A second short period of decline in the number of banks during the 1850 s occurred around the beginning of December 1858 when 29 banks went out of existence. Once again, the decline can be attributed in large part to the events in a single state, in this case Wisconsin. Like Indiana, Wisconsin had passed a free banking law in 1852 , and although the increase in the number of banks in that state was not as rapid as that in Indiana, the total increase in the number of banks was much larger. Wisconsin went from having only one bank in July 1853 to having 116 at the beginning of December 1858 . Fourteen of those banks went out of existence before the end of that year. The other 15 bank closings and failures at this time were spread across seven other states.

The third short period occurred from near the end of 1859 through the end of March 1860 when the number of banks in the country declined by 25 . Here the declines were spread across eight states, with the largest declines occurring in Tennessee (10) and New York (7).

\section{Conclusion}

This article describes a newly constructed data set of the population of banks that existed during the period from the beginning of the United States to the start of the Civil War. These data contain the names and locations of all banks that went into business during this period and an estimate of the time interval during which each of the banks was in operation. The compilation is based on reported balance sheets, listings in banknote reporters, 
and data from secondary sources. The series I present contain a count of the number of banks in business daily by state. I argue that my series are superior to previously existing ones on the basis of consistency, accuracy, and timing. Obviously, I welcome any information that would lead to an improvement on my estimates.

\section{References}

Bentley, Julius Marvin. 1969. Financial institutions and economic development in Mississippi, 1809 to 1860 . Ph.D. dissertation. Tulane University, New Orleans.

Bryan, Alfred C. 1899. History of state banking in Maryland. Baltimore: Johns Hopkins Press.

Cable, John Ray. 1923. The bank of the state of Missouri. New York: Columbia University Press.

Cole, David M. 1959. The development of banking in the District of Columbia. New York: William-Frederick Press.

Dillistin, William H. 1942. Directory of New Jersey banks, 1804-1942. Moorestown: New Jersey Bankers Association.

-1946. Historical directory of the banks of the state of New York. New York: New York State Bankers Association.

Dowrie, George William. 1913. The development of banking in Illinois, 1817-1863. Urbana: University of Illinois.

Fenstermaker, J. Van. 1965. The development of American commercial banking: 1782-1837. Kent, Ohio: Kent State University.

French, Bruce H. 1965. Banking and insurance in New Jersey: A history. Princeton, N.J.: D. Van Nostrand.

Hasse, William Frederick. 1957. A history of money and banking in Connecticut. New Haven, Conn.: privately printed.

Haxby, James A. 1988. Standard catalog of United States obsolete bank notes, 1782-1866. Iola, Wis.: Krause.

Holdsworth, John Thom. 1928. Financing an empire: History of banking in Pennsylvania. Chicago: S. J. Clarke.

Huntington, C. C. 1915. A history of banking and currency in Ohio before the Civil War. Ohio Archaeological and Historical Quarterly 22 (July): 235-539.

Kelly, Denwood N., Armand M. Shank Jr., and Thomas S. Gordon. 1996. A catalogue of Maryland's paper money, 1790-1865. Part 2 of Money and banking in Maryland. Baltimore: Maryland Historical Society.

Krause, Chester L. 1994. Wisconsin obsolete bank notes and scrip. Iola, Wis.: Krause.

Lesesne, J. Mauldin. 1970. The bank of the state of South Carolina. Columbia: University of South Carolina Press.

Neale, Mabel Frances. 1933. The history of banking in Nebraska, 1854-1889. Master's thesis. University of Nebraska, Lincoln.

Root, L. Carroll. 1901. Twenty years of bank currency based on general commercial assets. Sound Currency 8 (December): 209-32.

U.S. Congress. House. Various Executive Documents, 1833-1860.

Walsh, John J. 1940. Early banks in the District of Columbia: 1792-1818. Washington, D.C.: Catholic University of America Press.

Weber, Warren E. 2003. Interbank payments relationships in the antebellum United States: Evidence from Pennsylvania. Journal of Monetary Economics 50 (March): 455-74.

Weems, Robert Cicero. 1952. The bank of the Mississippi: A pioneer bank of the Old Southwest, 1809-1844. Ph.D. dissertation. Columbia University, New York. 